\title{
Questioning the merits and demerits of electronic communication in Social Work ${ }^{1}$
}

\author{
Debatiendo sobre las ventajas y desventajas de la comunicación \\ electrónica en Trabajo Social
}

\author{
Emilia MARTÍNEZ-BRAWLEY \\ Arizona State University, Phoenix, Estados Unidos \\ eembasu.edu
}

Recibido: $22 / 01 / 2016$

Revisado: $17 / 02 / 2016$

Aceptado: 03/06/2016

Disponible on line: 01/07/2016

\begin{abstract}
This paper examines the social dynamics of electronic exchanges in the human services, particularly in social work. It focuses on the observable effects that email and texting have on the linguistic, relational and clinical rather than managerial aspects of the profession. It highlights how electronic communication is affecting professionals in their practice and learners as they become acculturated to social work. What are the gains and losses of the broad use of electronic devices in daily lay and professional, verbal and non-verbal communication? Will our current situation be seriously detrimental to the demeanor of future practitioners, their use of language, and their ability to establish close personal relationships? The paper analyzes social work linguistic and behavioral changes in light of the growth of electronic communication and offers a summary of merits and demerits viewed through a prism emerging from Baron's (2000) analysis of human communication.
\end{abstract}

Keywords: electronic communication, merits and demerits, social work relationships, professional development and electronic communication, email and texting in Social Work

\section{Resumen ampliado}

Este ensayo ofrece una reflexión sobre la comunicación electrónica en Trabajo Social. Se enfoca en los efectos lingüísticos, en las relaciones profesionales y en la práctica clínica que el uso de correos y mensajes electrónicos tienen actualmente. Enfatiza como afecta la comunicación electrónica a los profesionales en su práctica y a los estudiantes que aspiran a la profesión. ¿Cuáles son las ventajas y desventajas del uso diario de varios medios electrónicos en el diálogo (verbal y no verbal) del profesional y del cliente? ¿Afectará esta situación al comportamiento y la sociabilidad de los profesionales en el futuro? ¿Qué ocurrirá con su lenguaje y capacidad de establecer relaciones constructivas? Este ensayo ofrece una sinopsis de las ventajas y desventajas a través de un prisma establecido por el modelo de Baron (2000).

En el artículo se examinan la dinámica social y los antecedentes históricos de los intercambios electrónicos en los servicios humanos, en particular en Trabajo Social. Se centra en los efectos observables que tienen la comunicación electrónica, principalmente el correo electrónico y los mensajes de texto, en los aspectos lingüísticos, relacionales y clínicos más que en el ámbito de la gestión. Se pone de relieve cómo está afectando la comunicación electrónica en la práctica de los profesionales y de los alumnos, en el proceso de formación en Trabajo Social. Muchos autores han debatido la cuestión de cómo ha cambiado la práctica con la influencia de la comunicación electrónica; la mayoría de ellos han optado por aceptar la realidad como un hecho que es improbable que cambie (Finn, 2006). Algunos han abordado los nuevos dilemas éticos que surgen como resultado de la nueva situación (Escariador, 2013), incluso aportando sugerencias sobre cómo administrar el correo electrónico del cliente (Zur, 2011). Muy pocos han abordado la cuestión desde la perspectiva de cómo afecta el lenguaje a la ética y la práctica del Trabajo Social y la forma en que puede limitar la práctica el uso del lenguaje reduccionista, intrínseco a la comunicación electrónica. Los planteamientos que se exponen giran en torno a las consecuencias de esas limitaciones, ya que se realiza un análisis de cómo afectan estos cambios del lenguaje al comportamiento de los futuros profesionales y a su capacidad de establecer relaciones personales cercanas. Visto el incremento de la comunicación electrónica, se presenta asimismo un resumen de las ventajas e inconvenientes de la realidad actual.

En el resumen y en las conclusiones se realiza un análisis de la relación coste-beneficio, de las ventajas y desventajas. Así no todos los cambios producidos por la comunicación electrónica en Trabajo Social han sido negativos. La mayoría coincide en que la comunicación electrónica es una manera fácil y rápida de incrementar la divulgación, de experimentar conexiones con otros, dentro del contexto de «el comportamiento y las interacciones engendradas en el ciberespacio» (Finn,

1 An expanded theoretical discussion of some of the themes in this essay will appear as a chapter in: Turner, F. (2016). Social work treatment. Interlocking theoretical approaches. Forthcoming Sixth edition. Oxford: University Press Social Work Theories and Practice. 
1999; Barak, 2008). Las innovaciones tecnológicas del siglo XXI han maximizado, sin duda, el número de personas con las que uno puede ponerse en contacto a la vez, lo que permite eludir la repetición de mensajes similares a diferentes personas (Wilson, 2011). Pero «cualquier economista dirá que siempre se debe realizar un análisis de rentabilidad y que la influencia de la electrónica en la era de la información tiene importantes costes» (Wilson, p. 1). Pocos autores en el ámbito del Trabajo Social han realizado análisis de costes y beneficios y sus escritos por lo general no se han difundido adecuadamente. En realidad, se puede indicar que todavía nos encontramos ante un gran debate sobre si nuestra utilización cada vez mayor de la tecnología para comunicarse con los demás ha aumentado o disminuido la personalización; si la sociedad se ha vuelto más o menos anómica; y si ha ayudado u obstaculizado la capacidad de las personas para resolver los problemas de interacción. La literatura sobre las consecuencias de la tecnología en profesiones, como la de Trabajo Social, no es abundante. Autores - como Howe, 1996; Webb, 1996 y 2006; Finn, 2004; Barnett-Queen, 2001; Parton, 2008; Parrott y Macdoc-Jones, 2008; Brownlee, Graham, Doucette, Hotson \& Halverson, 2010; y algunos otros - han abordado con frecuencia el tema desde puntos de vista bastante opuestos. Algunos han señalado el valor potencial de la tecnología para la gestión y grabación de datos, pero incluso en las zonas rurales, donde los profesionales son escasos, y los mensajes electrónicos pueden aumentar la frecuencia de los contactos, se plantea la duda de si tendrán más ventajas las soluciones estandarizadas. Belanger (2013) ha sugerido que la tecnología ha eliminado puestos de trabajo de las zonas rurales y la responsabilidad local, que es, después de todo, la primera línea de defensa cuando surgen problemas graves de salud mental, de salud general o de servicios sociales (Kowalenko, Graham, Doucette, Hotson, \& Halverson, 2003). Otros han expresado serias preocupaciones por los cambios que ha requerido la tecnología en las prioridades de la práctica y del modus operandi de los trabajadores sociales. Ponen en duda la ventaja de la comunicación electrónica aplicada a todos los aspectos del Trabajo Social, afirman que la práctica del Trabajo Social se ha convertido en estandarizada y despersonalizada, y les preocupa que este modelo perjudique el desarrollo de los profesionales de Trabajo Social. En el Cuadro 1 se intenta captar, aunque sea en síntesis, lo que está sucediendo realmente en la práctica profesional actual (prestación de servicios) de los trabajadores, así como en los ámbitos personales.

Los cambios en la forma en que los individuos en la cultura dominante usan el lenguaje tienden a ser sancionado por los educadores y por el público. Como profesores de Trabajo Social, desarrollamos la «normatividad» en la profesión, nuestra actitud actual de la aceptación pasiva y el apoyo incondicional a todas las formas de comunicación electrónica parecen disuadir a los profesionales de expresar las dificultades que encuentran. Es necesario que los profesores de Trabajo Social en la Universidad validen la importancia de practicar la habilidad del desarrollo de la comunicación cara a cara y la relación, además de la posibilidad de utilizar los medios electrónicos. La necesidad de rapidez en la comunicación y la proliferación de las encuestas, no siempre apropiadas, invitan a los profesionales a aceptar sin quejarse lo que parece ser el evangelio actual de la comunicación electrónica, por encima y más allá de sus límites. Las dudas que se articulan en torno a la comunicación electrónica en los servicios sociales y en el Trabajo Social, ya sea entre el cliente y el trabajador o entre colegas, se expresan en voz baja debido a que las críticas suenan como amenazas al paradigma. Los trabajadores sociales no quieren parecer contrarios al progreso o a las tendencias contemporáneas. Los profesionales son plenamente conscientes de que los clientes del Trabajo Social se encuentran, con frecuencia, aislados o fuera de la interacción humana directa, y de que se sienten incómodos con la comunicación escrita. A pesar de esto, los efectos de la comunicación electrónica tienden a ser aceptados en lugar de analizados u objetados; lo mismo ha ocurrido con las consecuencias de la comunicación electrónica, o la naturaleza y la calidad del lenguaje utilizado, o la relación entre el cliente y el trabajador o entre colegas, o los resultados de la comunicación. Estas áreas tienen un efecto significativo en la formación de los futuros profesionales y sobre el futuro de las profesiones de ayuda. Los profesionales de la educación ya no pueden observar plácidamente la descontextualización de los servicios, la eliminación de los aspectos humanos fundamentales de la ayuda con el pretexto de la eficiencia, la rapidez o la fiscalidad. El intercambio de mensajes enviados y recibidos no presupone que se haya producido la comunicación (Pfeiffer, 1998, p. 1). Hay muchas circunstancias que dificultan la comunicación efectiva: la comunicación es siempre un toma y daca que involucra pensamientos, sentimientos y «receptividad respecto a los intentos de otros de compartir aspectos similares» (idem). Debe empezar a producirse un diálogo serio y honesto acerca de lo que puede y no puede hacerse electrónicamente en Trabajo Social. El lenguaje, el procedimiento y las relaciones cara a cara siempre han sido herramientas fundamentales en la prestación de servicios y en la comunicación efectiva de servicios humanos.

Palabras clave: comunicación electrónica, ventajas y desventajas, relaciones profesionales en el Trabajo Social, desarrollo profesional y comunicación electrónica, correo y mensajes electrónicos en el Trabajo Social.

Referencia personalizada: Martínez-Brawley, E. (2016): «Questioning the merits and demerits of electronic communication in Social Work». Cuadernos de Trabajo Social, 29(2): 173-183.

Summary: Introduction. 1. What has happened to language? 2. Computers in the Human Services and their role in what happened. 3. What happened to Personal Relationships in the Electronic Age: Is Social Work the Same? 4. Summary and Conclusions: A Cost-Benefit Analysis of the Merits and Demerits. 5. References. 


\section{Introduction}

This paper examines the social dynamics and historical background of electronic exchanges in the human services, particularly in social work. It focuses on the observable effects that electronic communication, mainly email and texting, have on the linguistic, relational and clinical rather than managerial aspects of the profession. It highlights how electronic communication is affecting professionals in their practice and learners as they become acculturated to social work. Many authors have discussed the matter of how practice has changed with the influence of electronic communication, most of them adopting an understandable resignation about a reality unlikely to change (Finn, 2006). Some have addressed new ethical dilemmas appearing as a result (Reamer, 2013), even given suggestions on how to manage the email client (Zur, 2011). Very few have approached the matter from the perspective of how language affects the ethos and practice of social work and how the use of reductionist language, intrinsic to electronic communication, can limit a rich practice. The discussion that follows hinges on the consequences of those limitations as it reviews how changes in language affect the demeanor of future practitioners and their ability to establish close personal relationships. In light of the growth of electronic communication, a summary of merits and demerits of the current reality is also presented for consideration.

\section{What has happened to language?}

Every teacher and professor would attest to the fact that the use of verbal and written communication has changed radically with the advent of email and texting. Professors in higher education find it hard to ascertain whether the problems of written and oral communication that affect many students are the result of poor language training, inattention, discomfort with others or simply consequences of electronic communication that has turned all words into fleeting signals, as short-lived as a quick text-message among friends. Expressions of sentiments are trivialized by smiling faces or devil designs on the page and never taken very seriously. Baron (2000), a linguist, argues that our new use of language (including symbols on the internet) is affecting not only the linguistic but also the social dimensions of human interaction (p. 29). These are serious concerns that can be examined in relation to social work.

The decline of writing skills and concomitant analytic and critical thinking among students and young people has received broad consideration (Baron, 2000, 2008, 2009; Tait, 2000; Rosen, 2012). Assigned class papers often offer streams of consciousness. There is little time to spend on the most appropriate way to convey difficult concepts. There is no reward for either students or professionals to «mull over» the impact words have upon the reader. Students and professionals today seem unaware that writing is important in itself, because we live in a society where writing has become too practical and utilitarian (Dietrich, 1977; Fabricant, 1985; Parton, 1998, 2008; Webb, 2001). In this regard, in observing the way records are kept in social work today, writing appears to have been reduced to serviceable and mechanistic brief entries through computer-directed reductionist recordings (Parton, 2008; Webb, 2006). There is no chance for the worker to dwell on analysis or reflective wisdom. The recordings of encounters with clients are too brief to capture full elements of ambience, mood, verbal and non-verbal expressions. The art of social work, the emphasis on process and story, on affect among participants seems to have lost vitality, affecting the way in which social workers think, explore new subjects and develop practice and policies (Webb, 1996, 2006). Recordings are done in computer generated forms, which are dry and short, and resemble emails. For Tait (2000), these forms fall short in tone, subtlety, spontaneity and creativity.

A second observation in the electronic age pivots on ways of interacting. Ong (1982) suggested that oral speech systems develop «human beings into close-knit groups» (Ong, 1982, p. 72). Ong would have probably taken issue with the onset of email as preferred communication in today's workplace, particularly in social work, because ultimately he viewed the written word as unresponsive.

There are also other challenges. After electronic communication became pervasive, young people began to communicate through separate generational layers, developing their own systems of purported electronic intimacy. Young and older people today, communicate among their «layers» (layers of age, of class, interest, 
etc.). This presents a serious problem between worker and client communication. "Although electronic communication, at first glance appears to help maintain in-depth personal relationships, in actuality, it facilitates the opposite ... The ramifications of [the] increase of electronic communication are severe...» (Wilson, 2011, pp. 1-2). Wilson further predicts difficulties and fear of face- to- face relationships in the next generation. Turkle (2012) rightly asserted how this instant communication has created a culture of distraction in the young and the old. Her research on parents and children suggests that from the moment children «meet this (electronic) technology» they enter a culture of competition and inattention to the surrounding milieu. Parents text games instead of taking precious moments to talk to their children as they watch them on the playground, the back of the car, etc... In Turkel's views, children and parents "suffer the sling and arrows of not having» each other's attention from the earliest possible interactions (NPR, 2012, pp. 1-22). This inability to attend to others, in the deepest sense, has severe implications for social work whether at the individual, cross-generational, cross-racial or community levels.

New electronic media show little respect for cumulative wisdom of past generations, preferring to communicate many messages quickly over vast spaces allowing little time for absorption or reflection...The quantity and speed do not allow for sustained gazes into the depths of history or into the richness of particular ethnic, racial, or religious traditions (Schultze, 1991, p. 58).

Rosen (2012) suggested that «we are living in an age of electronic intimacy; its hallmark is «instantaneous global communication...» (p. 49). But this so called «instant intimacy» is in fact, quite false, because it implies, for many, the removal of the «other», the obliteration that there are other human beings involved in the interaction, and most importantly in the context in which these interactions take place. In the internet, we are not aware that we are with other human beings. In many ways, «we are disinhibited from taking into full account that we are in the presence of another human being》 (NPR, 2012, p. 15).

The phenomenon of electronic «dating» which has now taken over the U.S. tries hard to obtain small details about the individuals, their likes and dislikes, their hopes and aspirations, etc. but in the end, for those courageous enough to bring the process to concluding steps, it is in the meeting that people might communicate at a more intimate level. However, useful as these systems might be, they have removed "community» as it once existed and reduced personal interaction and ambient awareness. In a study of 60 undergraduate at American University, Baron found that as a group, the students reported 272 Facebook «friends». When questioned how many of them were «real friends» (namely, including personal interaction), the number plummeted to about 72 people with whom the students might actually interact (Baron, 2008, p. 89).

Lack of ambient awareness is pervasive and has now reached social work. As a social work professor, I have observed that when students are given group assignments which require that they coordinate with each other and contact external sources, they tend to handle interaction in the same way they handle writing. Not just students but often new professionals choose not to communicate in person, even when crisscrossing text messages and emails create confusion. Issues are seldom fully cleared. In spite of the usual and valid concerns about time, easy access, etc., the reluctance of many social workers to become involved in personal interactions appears to indicate that at least some workers are very uncomfortable with direct verbal communication.

During a recent community study, a group of graduate social work students complained about their own reliance on emails and the confusion emails created. «E-mailing felt like a barrier to me at times. I mistakenly believed the tasks were getting accomplished based on what individuals were telling me they had completed», commented one student. "All the communication was done over email, which became quite hectic», reported another. "The individuals in my group expressed lack of time to meet in person... [but] everyone was sending emails... making it hard to know what my group was doing specifically». Many more examples showed that the students felt trapped; on the one had email helped them communicate wholesale, but such willy-nilly contacts hindered progress in more meaningful ways.

Intimacy may be said to have become electronic, but is it real? While it may be argued that 
the message of a smile (perhaps light-hearted approval) is still occasionally conveyed (whether there is an actual smile or just the representation of a smile), one could also say that using a representation to convey what expressions have conveyed for centuries creates a disconnect between users of the representation and users of traditional communication. A great many social work students and some professionals today feel that spending time in face to face interactions is a waste of time rather than a valuable opportunity to learn about others.

Yet, the literature is clear on a number of dimensions in human communication all of which play a role in the social dynamics of any exchange (Baron, 2000). For example, Baron mentions the style, that is «the choices users make about how to convey semantic intent» (formality and normativeness); she also discusses «the physical parameters» of the message, that is the physical position or distance between those who are communicating: (Are they in the same room? On the phone? etc.); and the «relationships between the participants in the exchange», such as familiarity or degree of intimacy, etc. (p. 250). These dimensions, among others, are very useful to consider when dealing with electronic communication in social work today. We can take a bird's eye view of some of them.

A couple of decades ago, email, for example, appeared more like writing. Email was used in business and when used elsewhere, it had many of the formal contract-like qualities that made the participants relatively careful. In sociological terms, the communication was generally between subordinate and super-ordinate and retained many of these belaboring features. Practitioners in human services used emails to immediately record serious concerns with their supervisors; professors in social work seldom used it outside administrative or peer communication. Social work or human service students seldom emailed their professors with simple matters that could easily be asked of a peer. They certainly never emailed or «texted» other students in classes and were careful about the nature of the communication. Email in agencies, if used at all, was more formal inasmuch as everybody knew that while the other person could not be seen, the words on the page were not fleeting or disappearing signals and therefore had to be written with some care. The parties in the early email exchanges kept a certain level of formality and conveyed a certain demeanor. With broad dissemination of the emails and texting, the social dynamics and the relationships in the exchanges were transformed. The exchanges increased dramatically in numbers, speed and frequency of access was enhanced, but style became more casual, less complex; individuals became less mindful of the other person's responses, less concerned about demeanor, whether collegial or hierarchical.

Linguists point out that normativeness in language and social interaction goes in cycles. The use of words, the style, tone and formality of the prose bring about changes in social interaction. Standards are set by those we work for, write to, the media, etc. and definitely change through time. In the social services, the world around us, including bosses and educators have an important role to play in relation to what becomes acceptable but their hands may have been forced in recent decades by the overpowering growth of technology and by fiscal considerations. Social work has been caught in a new normativeness of social interaction driven by the use of technology and electronic communication.

Without going into over-analysis, the same can be said for the physical parameters in which messages are exchanged and the nature of the relationship of those who exchange the messages. Electronic communication has affected all of them in social work.

\section{Computers in the Human Services and their role in what happened}

Between the early days of email and today, there came enormous changes in the use of computers in human services. Critiques about lack of transparency record keeping in contacts between workers and clients, for example, brought about not only greater scrutiny but also further technocratization (Parton, 2006). Workers were handed computers and forms that could be taken to home visits, and the nature of the relationships and contacts with clients was changed by the computer as an intermediary. Today, while encounters appear - and some cases are- more transparent, they are prescribed and recorded according to pre-established categories. Only certain highlights can be «objectively» noted in the record; those are typically overtly observable and easy to include in a checklist. What can be recorded in a form becomes the center of the interview. Many 
might blame this change on current risk management practices related to the use of discriminatory language. But in reality, «politically correct» speech relates only to the use of clearly offensive language. The more constraining aspects are not «political correctness» but related to the fact that social agencies today are governed by a business or efficiency ethos and workers, faced with demands for fast «productivity» have become convinced that shedding the burden of personal interaction with clients and colleagues is required for efficiency. The tension between efficiency and speed has been highlighted in a recent article in the Atlantic (Lukianoff $\&$ Haidt, 2015). The article points out that «cognitive behavioral therapy» is perhaps the most popular therapeutic approach in the U.S. today. The goal of cognitive behavioral therapy is to correct and minimize distorted thinking. But, we must ask ourselves, can we correct our thinking if we cannot be serious about the fullness of our language, if we cannot be detailed rather than reductionist? Computers force us into reductionist thinking. However, reductionist thinking cannot be of help in cognitive behavioral dialogue, which is, in essence, an essentially philosophic musing. In social work education, computers while tremendously helpful in many ways, force students and professors into thinking non-critically rather than into enhancing our critical thinking skills of analyzing and exploring alternatives.

In 2001, Fabricant wrote about the «industrialization of social work», documenting the loss of the craft and artistic elements in favor of bureaucratic responses and «one size fits all» solutions (p. 390). This trend toward standardization and technocratization was part of a fiscal situation in the 1980s and 90s. Clients, for the business side of even human service organizations, began to resemble the raw material in an assembly line that counted inputs and outputs. Per force, the emphasis was placed on the individual characteristics of the client rather than on the social milieu; individual concerns could be documented much faster and «devolved» by professionals who carried out very specific functions within very specialized «silos» in the agency structure. Social workers' moved from a more contextual and holistic paradigm to one that focused on specificity and fast communication. Howe (1996) commented that the emphasis in social work was dangerously changing from a focus on internal meaningful psychological functioning to the externals of behavior. Parton (2008) documented this sad state of affairs. He stated:

A central part of my argument is that the nature of practice and the knowledge which both informs and characterizes it is increasingly less concerned with the relational and social dimensions of the work and more with the informational. Increasingly, it seems that the key focus of activity of social work and social care agencies is concerned with the gathering, sharing and monitoring of information... It is not my argument that these are new activities but that they have taken on a much greater significance in recent years because of the growing importance of ICTs... (p. 254)

These developments minimized not only the artistic ties of social work but also its relational aspects (Goldstein, 1991; Martinez-Brawley \& Zorita, 1998). This is commented upon even by authors who can be said to «favor» the broad application of technology in social work. With computers, problems need to be reduced to in technically neutral terms. «In essence, compliance is required to meet the technical processes of the computerized care management system. The process further limits professional freedom and directs actions only towards «approved» activities» (Parrot \& Madoc-Jones, 2008, p. 186). Reductionist thinking in social work coincided with the broad spread of computers and emails. Agencies invested heavily in electronic equipment and workers sometimes reluctantly and sometimes willingly became acculturated to the new systems. Speed won over reflection. Today, there is no time for relationship building within agencies and thus relationships and communication with others appear somewhat antiquated. Workers cannot afford to develop sound judgment through reflection and circumspection: «Reflective judgment, which represents the virtuous man, is a sifting process of circumspection. It develops wisdom by engaging us in the process of the cultivation of good judgment» (McBeath \& Webb, 2002, p. 1024).

Additionally, as has already been said, the physical parameters of the message have changed. Colleagues who are placed next to each other in an office may not talk to each other or show camaraderie but are encouraged to email 
each other. This extends to clients (who are often referred to as «consumers»). The emails serve two purposes: first, they allow the workers to document that they have taken action, «devolving» the case to «specialists» or closing it promptly; and secondly, to show that workers do not spend time in «useless» conversation with colleagues.

The advent of the personal computer that could be carried everywhere and the I-phone, where people can instantly reach one another by email or text, probably encourage atomistic behavior. But naturally, emails are not intended to express complex thoughts and texting is not required to be literary. The nature of the new systems of communication encourages grammatical deterioration. In Baron's scheme, «the lexical and syntactic aspects of the message» are no longer a major concern. Speed and simplicity is what personal computers aim for. The choices users «make about how to convey semantic intent» cannot be focused on smoothness or softer tones. The flow of the prose in electronic communication is not intended to be literary. Of course, these linguistic changes, though apparently superfluous, have serious consequences for the way the public and social workers approach the world of relationships (Harlow \& Webb, 2003; Garrett, 2005).

\section{What happened to Personal Relationships in the Electronic Age: Is Social Work the Same?}

Psychologists believe that conversation is one of the most human things we can do. In his book the De-Voicing of Society, Why we don't talk to each other anymore, Locke (1998) suggested that by using not just the telephone but voice mail, email, and texting, we're decreasing the non-verbal «signals we choose to project in the act of communicating with each other» (Baron, 2000 , p. 10). Social workers know that personal relationships have been traditionally the means through which basic social needs are expressed and potentially satisfied and the cornerstone of practice. Until recently, our understanding of community counted on human, personal face-toface communication as the main means to share, resolve or alleviate our social concerns. It has been amply shown-as any television fan of Downton Abbey would attest, that older people were opposed to the use of the telephone when it first appeared in homes at the turn of the $20^{\text {th }}$ Century, and social workers are not an excep- tion. But, for many decades now, social workers in the industrial world have had to expand notions of social support beyond face-to-face contact to include larger and less personal networks. Yet, until very recently, they still counted on some form of direct communication and personal human contact to complete the communication loop. But today we stay on line, denying all forms of community participation while talking about the importance of our partaking in them (Cassani-Davis, 2015).

When mental health workers discuss experimental electronic mental health treatment, they typically report a number of concerns that need to be resolved to improve the results of e-contacts. For example, it is important to know how well the consumer is able to read and write in text-based communication. Another common concern is that the loss of visual and auditory feedback between therapist and consumer may affect the ease of communication and lead to greater potential for miscommunication. Also, concerns are expressed about breaking the therapeutic alliance between client and therapist in an e-communication environment. Practitioners who observe intense e-communication activity report that face-to face meetings can accomplish more than technology, particularly «to resolve a serious conflict or support someone in emotional stress» (Sherman, 2013).

Referring to technology in rural human services, particularly in child welfare, Belanger (2013) expressed concern about the local community losing responsibility for its children and families. While she calls this a subtle demerit, the fact that the responsibility for the care and nurturing of children, is centralized to a remote electronic intake location presents serious difficulties. Investigations and services are decontextualized and local resources are not used in keeping children safe. Among children themselves, similar de-contextualization has been reported. «Kids who text each other a dozen times a day ignore each other when they meet in the flesh», reported a school counselor (Sherman, 2013). A number of college professors are quoted with a variety of observations about students' failure to communicate in higher education (Weeks, 2012). And of course, Turkel (2015) recently further expressed the seriousness of the problem of lack of conversation in the workplace, the schools and family life. 
Social Work by its very nature never addressed problems outside their social context, not even when emphasizing psychological factors. Social workers emphasize the social and interactional dimensions of being. Social work's roots are heavily embedded in practice in macro contexts (the settlement houses and other community movement). Even during the psychological (primarily Freudian) period of the 1930s, 40s, and 50s, social workers did not stop emphasizing the value of close networks of support, whether it be for acculturating the young or the newly arriving immigrant, or for offering material and emotional support to the poor, the sick, the emotionally frail, the elderly or the lonely. As close as a couple of decades ago, social work training stressed the importance of the various signals of communication - the voice, the words, the gestures, the gaze, how practitioners invite or reject closeness from someone with whom dialogue is established, the empathy they can communicate or the distance they can unintentionally create. Social workers debate the cultural nuances of native and acquired languages, the gestures that accompany speech in various cultures, and even the use of translation in direct practice because they doubt the fidelity of negotiating close communication through intermediaries, who necessarily add or detract dimensions to the interactional equation.

In her most recent book, Reclaiming Conversation: the Power of Talk in a Digital Age (2015) , Turkle argues that emails, facebook, instant messages, and many other forms of «instant») purported communication are harming our ability to converse face-to-face with each other, which is «the most human thing we do». Turkle has a number of observations from her research with students, children and her direct observations of people, observations which social workers need to heed. She believes that young people are beginning to realize the psychological incompleteness of electronic messages and predicts (as well as hopes) that there will be a trend and a rebellion among the young to reclaim conversation. But Turkle is still concerned whether adults will do the same. She observed adults at dinner, sitting at a table for two people, talking on their phones and each other at the same time. But experiments show that when you have a phone between two people at a conversation, the people feel less connected. In fact, Turkle uses the phrase «loss of empathy» to describe what happens (Cassani-Davies, 2015). This research should be very concerning to social workers. The hope is that our awareness of the danger or demerits of the electronic tsunami social work has embraced without apparent qualifications will become more apparent as we further pursue its consequences.

\section{Summary and Conclusions: a Cost-Benefit Analysis of the Merits and Demerits}

As has been noted, not all changes brought about by electronic communication in social work have been negative. Most agree that e-communication is an easy and fast way to increase disclosure, to experience «mind-to-mind» connections with others within the context of «the unique behavior and interactions engendered in cyberspace» (Barak, 2008; Finn, 1999). The technological innovations of the $21^{\text {st }}$ century have certainly maximized the number of people one can contact at one time, saving us from repeating the same basic messages all over again to many individuals (Wilson, 2011). But, «any economist would tell you that you should always perform a cost benefit analysis and the influence of electronics in the information age has severe opportunity costs» ( $p$. 1) A few social work thinkers have been performing such cost-benefit analyses but their writings are typically not well-disseminated.

In fairness, there is still a great deal of debate as to whether our ever increasing use of technological means to communicate with others has increased or decreased personalization, whether it has made society more or less anomic and whether it has helped or hindered the ability of individuals to resolve interactional problems. The literature on the consequences of technology in professions such as social work is not abundant. Authors such as Howe, 1996; Webb,1996, 2006; Barnett-Queen, 2001; Finn et al, 2004; Parrott \& Macdoc-Jones, 2008; Parton, 2008; Brownlee, Graham, Doucette, Hotson, \& Halverson, 2010) and a few others have approached the subject often from quite opposite points of view. Some have addressed the potential value of technology for management and recording, but even in rural areas, where practitioners are scarce and electronic messages can increase the frequency of contacts, there is still the doubt that standardized solutions have much merit. Belanger (2013) has suggested that technology has removed jobs from rural are- 
as and has lifted local responsibility, which is, after all, the first line of defense when serious mental health, health or social service issues arise (Kowalenko, Graham, Doucette, Hotson, \& Halverson, 2003). Others have expressed serious concerns about the changes that technology has required in the practice priorities and modus operandi of social workers. They question the merit of electronic communication applied to all aspects of social work in on-going practice. They state that social work practice has become standardized and de-personalized and worry that this model will be detrimental to developing social work practitioners. The following figure attempts to capture, albeit in synthesis, what is actually happening in the current e-environment in practice at the workers' professional (service delivery) and personal levels.

Changes in the way individuals in the mainstream culture use language tend to be sanctioned by educators and the public. As social work educators, we develop «normativeness» in the profession. Our current attitude of passive acceptance and unquestioning support towards all forms of e-communication appears to be deterring professionals from voicing the difficulties encounter. Social work academics need to validate the need to practice the skill of face-to face communication and relationship development in addition to what might be possible electronically. The speed of our communication and the proliferation of quick and often badly honed «surveys» entices professionals to accept without complain what appears to be the current gospel of e communication above and beyond its limits. The doubts that are articulated about e-communication in the human services/social work, whether between client and worker or among colleagues are expressed a sotto voce because criticisms sound threateningly anti-paradigmatic. Social workers do not want to appear luddites or go against the most contemporary trends. Professionals are fully aware that the clients of social work are often isolated or estranged from direct human interaction and frequently uncomfortable with communicating in written text. In spite of this, the effects of electronic communication have tended to be adopted rather than analyze or objected to. Neither have the consequences of electronic communication, or the nature and quality of the language used, or the demeanor shown between client and worker or colleagues, or the results of communication that occurred or not occurred been reviewed. These areas have significant effect in the training of future practitioners and on the future of the helping professions. Professional educators can no longer placidly observe the de-contextualization of services, the removal of the most fundamental human aspects of helping under the guise of efficiency, speed or fiscal realities. The fundamental transaction of message sent and received does not presuppose that communication has occurred (Pfeiffer, 1998, p. 1). There are many cir-

\begin{tabular}{|c|c|c|c|}
\hline \multicolumn{2}{|c|}{ Professional } & \multicolumn{2}{|c|}{ Personal } \\
\hline Merits & Demerits & Merits & Demerits \\
\hline $\begin{array}{l}\text { - Speed } \\
\text { - Perceived Efficiency } \\
\text { - Mobility } \\
\text { - Increased accessi- } \\
\text { bility to information } \\
\text { - Accountability } \\
\text { - Claims of financial } \\
\text { savings } \\
\text { - Transparency } \\
\text { - Access and deli- } \\
\text { very to rural and remo- } \\
\text { te locations }\end{array}$ & $\begin{array}{l}\text { - Technocratic inste- } \\
\text { ad of personal services } \\
\text { - Decreased personal } \\
\text { relationships } \\
\text { - Increased depart- } \\
\text { mental separation in } \\
\text { agencies } \\
\text { - Loss of workers' in- } \\
\text { terpersonal skills } \\
\text { - Difficulties with fa- } \\
\text { ce-to-face interactions } \\
\text { - Decontextualized } \\
\text { help } \\
\text { - Loss of jobs for real } \\
\text { people in service deli- } \\
\text { very }\end{array}$ & $\begin{array}{l}\text { - Speed } \\
\text { - Access to people at } \\
\text { all times } \\
\text { - Access to people in } \\
\text { remote locations } \\
\text { - Can facilitate a type } \\
\text { of intimacy }\end{array}$ & $\begin{array}{l}\text { - Lack of meaningful } \\
\text { human contact } \\
\text { - Reduced face-to fa- } \\
\text { ce intimacy } \\
\text { - Increases linear ra- } \\
\text { ther than creative thin- } \\
\text { king } \\
\text { - Favors the techno- } \\
\text { cratic paradigm and the } \\
\text { use of «prescribed» and } \\
\text { formulaic interactions } \\
\text { and solutions }\end{array}$ \\
\hline
\end{tabular}


cumstances that hinder effective communication: communication is always a give and take that involves thoughts, feelings and «receptiveness to the attempts of others to share similar data» (idem). A serious and honest dialogue about what can and cannot be done electronically in social work must commence. Language, demeanor and face-to-face relationships have always been fundamental tools in service delivery and effective human service communication.

\section{References}

Abbott, J.; Klein, B.; \& Ciechomski, L. (2008). Best practices in online therapy. Journal of Technology in Human Services, 26, (2-4), 360-375. doi: 10.1080/15228830802097257

Barnett-Queen, T. (2001) Attitudes and opinions regarding the use of the internet for continuing education among social workers. Journal of Technology in Human Services, 18(3-4), 145-169.

Baron, N. (2000). Alphabet to email. How written English evolved and where it's heading. London \& New York: Rutledge.

Baron, N. (2008). Always on. Language in an online and mobile world. New York: Oxford University Press.

Baron, N. (2009). Are digital media changing language? Educational Leadership, 66(6), 42-46. Retrieved from http://eric.ed.gov/?id=EJ834078

Barak, A. (2008). Psychological aspects of cyberspace: Theory, research, applications. New York: Cambridge University Press.

Belanger, K. (2013). Technology in rural human services: The good, the bad and the ugly. Rural Assistance Center Newsletter. http://www.raconline.org/newsletter/summer13/focus.pho?utm_source+rura... 8/13/2013

Brownlee, K.; Graham, J.; Doucette, E.; Hotson, N.; \& Halverson, G. (2010). Have communication technologies influenced rural social work practice? British Journal of Social Work, 40, 622-637. doi: 10.1093/bjsw/bcp010

Cassani-Davis, L. (2015). The flight from conversation. The Atlantic, October 7, 1-8. Retrieved from http://www.theatlantic.com/technology/archive/2015/10/reclaiming-convers... Jan. 11, 2015

Dieterich, D. (1977). The decline in student writing skills: An ERIC/RCS interview. College English, 38(5) 466-472. Retrieved from http://www.jstor.org/stable/376383

Fabricant, M. (1985). The industrialization of social work. Social Work, 30(5), 389-395. doi: $10.1093 / \mathrm{sw} / 30.5 .389$

Finn J. (1999). An exploration of helping processes in an online self-help group focusing on issues of disability. Health in Social Work, 24(3), 220-231. Retrieved from http://www.ncbi.nlm.nih.gov/ pubmed/10505283

Frennert, S.; Forsberg, A.; \& Östlund, B. (2013). Elderly people's perceptions of a telehealthcare system: Relative advantage, compatibility, complexity and observability. Journal of Technology in Human Services, 31(3), 218-237. doi:10.1080/15228835.2013.814557

Goldstein, H. (1992). If social work has not made progress as science, might it be an art? Families in Society, 1, 48-55

Howe, Howe D.(1992). Child abuse and the bureaucratisation of social work. Sociological Review, 40, 491-508.

Kowalenko, N.; Graham, J.; Doucette, E.; Hotson, N.; \& Halverson, A. (2003). Rural workforce development and staff support: Remodeling service provision for early intervention in child and adolescent mental health. Australian Psychiatry, 11, 110-15. doi: 10.1046/j.1038-5282.2003.02007.x

Libresco, L. (2014). Can Google search for friendship? The American Conservative, May 20. $\mathrm{http} / / / \mathrm{www} \cdot$ theamericanconservative.com/articles Retrieved 6/2/2014

Locke, J. L. (1998). The de-voicing of society. Why we don't talk to each other anymore. New York: Simon and Schuster.

Martinez-Brawley, E., \& Zorita, P. (1998). At the Edge of the Frame: Beyond Science and Art in Social Work. The British Journal of Social Work, V. 28(2), 197-212.

McBeath, G., \& Webb, S. (2002). Virtue ethics and social work: Being lucky, realistic, and not doing ones duty. British Journal of Social Work, 32(8): 1015-1036. doi: 10.1093/bjsw/32.8.1015 
Ong, W. (1982). Orality and literacy: The technologizing of the world. (2nd Ed). New York: Routledge.

Parrott, L., \& Madoc-Jones, I. (2008). Reclaiming information and communication technologies for empowering social work practice. Journal of Social Work, 8(2), 181-97. doi:10.1177/ 1468017307084739

Parton, N. (2003). Rethinking professional practice: The contributions of social constructionism and the feminist 'ethics of care'. British Journal of Social Work, 33, 1-16. doi: 10.1093/bjsw/33.1.1

Parton, N. (2008). Changes in the form and knowledge in social work: From the 'social' to the 'informational'. British Journal of Social Work, 38, 253-269. doi: 10.1093/bjsw/bc1337

Pfeiffer, J.W. (1998). Conditions that hinder effective communication. In The Pfeiffer Library, 6, (2nd Edition, Jossey-Bass/Pfeiffer).

Rosen, C. (2012). Electronic Intimacy. Wilson Quarterly, Spring, 36. Retrieved from http://www.wilsonquarterly.com/essays/electronic-intimacy

Sherman, F. (2013). Face-to-face communication and technology. Demand media. Chron. Retrieved from: http://smallbusiness.chron.com/facetoface-communication-technology-2070. 5/11/2013

Schultze, Q. (1991). Dancing in the Dark: Youth, Popular Culture, and the Electronic Media. Michigan: Wm. B. Eerdmans, Grand Rapids,. ISBN 0802805302.

Tait, A. (2000). Students and Attachment: The Nature of Electronic Relationships. Adults Learning (England), 11(10), 20-22. Retrieved from: http://eric.ed.gov/?id=EJ607578

Takashi, I. (2009). Social workers' use of the internet and e-amil to help clients in Virginia. Journal of Technology in Human Services, 27 (2): 127-140.

Turkle, S. (2012, October 17). In constant digital contact, we feel alone together, NPR, interview with Terry Gross. Retrieved from http://www.npr.org/templates/transcript.pho?story Id=163098594

Turkle, S. (215). Reclaiming Conversation: The Power of Talk in a Digital Age. Penguin Press.

Webb, S. (1996). 'Forgetting ourselves? Social work values, liberal education and modernity', Studies in the Education of Adults, 28(2), 224-40.

Webb, S. (2006). Social work in a risk society. Basingstoke, Hampshire: Palgrave Macmillan.

Weeks, L. (2012, April, 26). What we have here: A failure to communicate. NPR. Retrieved from http://www.npr.org/2012/04/26/151351550 Retrieved 5/17/2014

West, D., \& Heath, D. (2011, April). Theoretical pathways to the future: Globalization, ICT and social work theory and practice. Journal of Social Work, 11(2), 209-221. doi: 10.1177/ 1468017310386835

West, D., \& Heath, D. (2011, April). Theoretical pathways to the future: Globalization, ICT and social work theory and practice. Journal of Social Work, 11(2), 209-221. doi: 10.1177/ 1468017310386835

Wilson, C. (2011). Social media, email and texting: Are they creating superficial relationships? Scripps Voice, 14(6). Retrieved from http://voice.scrippscollege.edu2011/02/07/social-mediaemail-and-texting-are-they-creating-superficial-relationships/ 
